\title{
3 Dimensional Printing in Cardiology: Innovation for Modern Education and Clinical Implementation
} \author{
Putrika Prastuti Ratna Gharini ${ }^{1},{ }^{*}, \underset{\text { Nur Amin }^{5}}{\text { Herianto }}{ }^{2}$, Nurfian$^{3}$, Ferdinandus Bayu Satria $^{4}$, \\ ${ }^{1}$ Department of Cardiology and Vascular Medicine, Faculty of Medicine, Public Health and Nursing, Universitas Gadjah \\ Mada-Dr.Sardjito General Hospital, Universitas Gadjah Mada Academic Hospital, Yogyakarta, Indonesia \\ ${ }^{2}$ Department of Electrical and Information Technology Engineering, Faculty of Engineering, Universitas Gadjah Mada, \\ Yogyakarta, Indonesia \\ ${ }^{3}$ Department of Anatomy and Embryology, Faculty of Medicine, Public Health and Nursing, Universitas Gadjah Mada, \\ Yogyakarta, Indonesia \\ ${ }^{4}$ Research Assistance, Universitas Gadjah Mada Academic Hospital, Yogyakarta, Indonesia \\ ${ }^{5}$ Technician, Centra Teknologi Indonesia, PT
}

${ }^{*}$ Corresponding author:

Dr. Med. Putrika P.R. Gharini MD., - email: ikagharini@gmail.com

Address: Department of Cardiology and Vascular Medicine, Faculty of Medicine, Public Health and Nursing, Universitas

Gadjah Mada-Dr.Sardjito General Hospital, Jalan Farmako Sekip Utara Yogyakarta 55281

Manuscript submitted: September 26, 2018; Revised and accepted: October21, 2018

\begin{abstract}
Medical uses of three-dimension (3D) printing have advantages for many importances, such as tissue and organ fabrication, creation of prosthetics, and model structural anatomy. Visualization of 3-dimensional structure of heart for the importance of examination, management or education is not fully comprehensive describe toward the complexity of anatomical structure and also toward the illustration of medical procedure. The aim of this study was to identify the potential application of heart's $3 \mathrm{D}$ printing for the enhancement of case understanding for doctor, medical students or residents and also for patient and its family. A normal model of heart is used in this research to stimulate next 3D object in cardiology area.We retrieved data from patients' CT scan performed in Gadjah Mada University Hospital, Yogyakarta from December 2017 to March 2018. Our focus is on normal heart anatomy. Data from CT scan results are exported into Digital Imaging and Communications format (DICOM), then dimension measurement and threshold segmentation are performed using Mimics Medical 20.0 (Materialise) application. Finally the file must be exported into STL format due to final process to cut the desirable parts using Mesh editing application. After the final model has been done, then it will be printed by fuse deposition method to make a 3D object.The making and implementing 3D printingof heart model has many advantages for medical education especially for the doctor, medical students or residents and also for the patient and its family to be more aware on the condition of the heart. This study may stimulate another trial of using this technique into several heart abnormalities
\end{abstract}

Keywords:heart anatomy; 3D printing; medical education

\section{INTISARI}

Kegunaan medis dari pencetakan obyek tigadimensi (3D) memiliki manfaat untuk banyak kepentingan, seperti untuk merekayasa jaringan dan organ, pembuatan prostetik, dan model structural anatomi. Visualisasi struktur 3 dimensi jantung untuk kepentingan pemeriksaan,tata kelola atau edukasi pasien tidak sepenuhnya menggambarkan dengan jelas kompleksitas struktur anatomi dan juga ilustrasi prosedur medis tertentu. Tujuan dari penelitian ini adalah untuk mengidentifikasi kegunaan potensial pencetakan 3D jantung untuk meningkatkan pemahaman kasus untuk dokter, mahasiswa kedokteran atau dokter residen dan juga tentu untuk pasien dan keluarganya. Model jantung yang normal digunakan dalam awal penelitian ini untuk menstimulasi pembuatan objek 3D berikutnya di bidang kardiologi. Data diambil dari CT scan pasien yang 
dilakukan di Rumah Sakit Universitas Gadjah Mada, Yogyakarta dari Desember 2017 hingga Maret 2018. Fokus penelitian adalah pada anatomi jantung normal. Data dari hasil CT scan di ekspor ke dalam format Digital Imaging and Communications (DICOM), kemudian dilakukan pengukuran dimensi dan pengaturan ambang kontras dilakukan menggunakan aplikasi Mimics Medical 20.0 (Materialize). Pada tahap akhir, file harus di ekspor ke format STL karena proses akhir adalah memotong bagian yang di inginkan menggunakan aplikasi pengeditan Mesh. Setelah model akhir selesai, maka akan di cetak dengan metode deposisi terpadu untuk membuat objek 3D. Pembuatan dan penerapan pencetakan 3D model jantung memiliki banyak manfaat untuk edukasi medis terutama untuk dokter, mahasiswa kedokteran atau dokter residen dan juga bagi pasien dan keluarganya untuk lebih menyadari terhadap kondisi jantung. Penelitian ini juga di harapkan dapat menstimulasi pembuatan model lain menggunakan teknik ini ke dalam beberapa kelainan jantung.

\section{INTRODUCTION}

A 3D printing is a promising technique that may have applications in medicine. Additive manufacturing, also known as 3D printing, is the process of creating physical objects by adding successive layers of material in different shapes. This process has become more practical and affordable. ${ }^{1}$ Medical uses of 3D printing have advantages for many importances, such as tissue and organ fabrication, creation of prosthetics, and model structural anatomy. ${ }^{2}$

Visualization of 3 dimensional structure of heart for the importance of examination, management or education is not fully comprehensive describe toward the complexity of anatomical structure and also toward the illustration of medical procedure for doctor to threat patient, medical students or residents, and also for patient and it's family. 3D printing is a technique to change and to create digital object into a real object with the same shape, size and details ${ }^{3}$. The rapid development of this technique makes a new learning tools for medical education. The ability to create a real physical model from CT scan can demonstrates the anatomical structure and its abnormality which experienced by patients. ${ }^{4}$

Application of 3D printing technique especially for cardiovascular disease in developing country is not fully developed yet. The aim of this study was to identify the potential application of heart's 3D printing for the enhancement of case understanding for doctor, medical students or residents and also for patient and its family. A normal model of heart is used in this research to stimulate next 3-D object in cardiology area.

\section{METHODS}

We retrieved data from patients' CT scan hospitalized in Gadjah Mada University Hospital, Yogyakarta from December 2017 to March 2018. Our focus is on normal heart anatomy. Data from CT scan results are exported into Digital Imaging and Communications format (DICOM), then dimension measurement and threshold segmentation are performed using Mimics Medical 20.0 (Materialise) application. Finally the file must be exported into STL format due to final process to cut the desirable parts using Mesh editing application. After the final model has been done, then it will be printed by fuse deposition method to make a 3D object. Fuse Deposition Method (FDM) is chosen because of the needs of accuration, appearance, surface object, and the strength of ingredients property. FDM is based on the melting and extrusion of a polymer filament. The polymer filament will be processed begin from the melting process that ending in a nozzle, forming a thread, and shaping the thread into a plastic part until we got an object same as in the STL file. ${ }^{5}$

\section{RESULTS}

The first step to create a model for medical education using $3 \mathrm{D}$ printing is defining the educational objective. In this research a normal heart is used. For planning the 3D prototype, there aresome essential characteristics of the model should be considered with the educational need. There are size, surrounding structures, surgical manipulation, accuracy and resolution of the model $^{4}$. The procedure that must be performed is divided into several stages with 
several different software, the difference between rigid and elastic printing is only on the machine settings and the addition of a guide on the machine. The following is the process carried out to print 3D models with 3D printerwith rigid and elastic material :

- Making a model, modeling is done using a computer and data inputted from CT Scan. This data is in the form of DICOM and processed into an STL file that can be processed into objects from 3D print

- STL cannot be directly used to command the machine, STL must be changed to G-Code or commonly called $G$ code. $G$ code is the machine language that is controlled by the computer. This code contains the position that must be achieved by the machine so as to produce a shape according to the STL and the model that has been input from the previous process

- Printer preparation phase, before initiate printing, the 3D printer must be calibrated. This calibration is done automatically by the 3D print machine. This calibration is in the form of checking the axis totaling 3 pieces, namely $X, Y$, and $Z$. The axis is calibrated so that the results of precision printing.

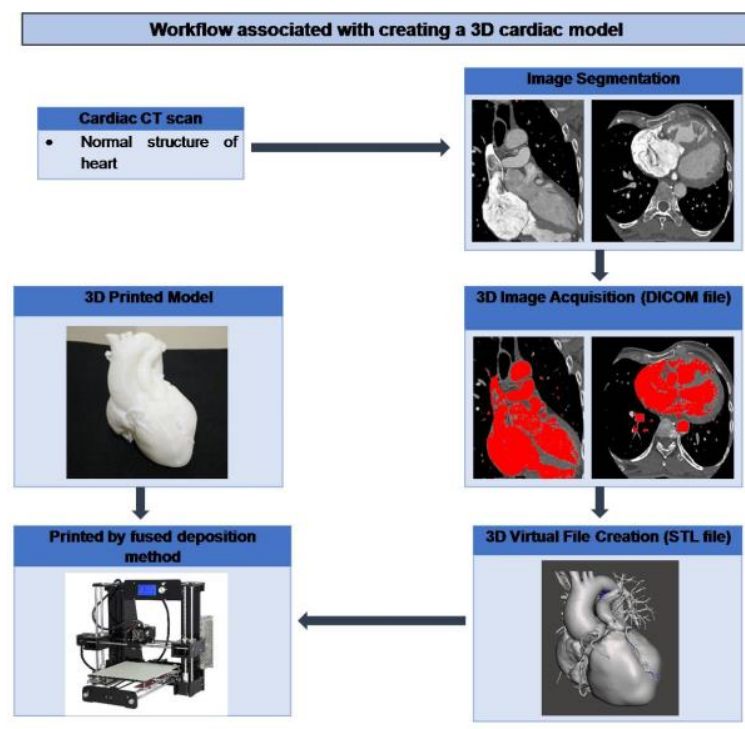

Figure 1. The step to make 3D object from CT scan file
- Preheat Filament, preheat or preheat for filament with PLA material. PLA has a melting point of $200^{\circ} \mathrm{C}$ and changes the glass transition at $60^{\circ} \mathrm{C}$. This heating is useful for checking whether the jamming nozzle channel or not. Jamming will be easily validated if the heated filament with a temperature of $200{ }^{\circ} \mathrm{C}$ does not melt down.

- Printing phase, in the Centralab Gateform C-01 printer the printing stage uses SD Card as a storage medium for the G-Code. These printers only need to select the file you want to select and click print. The machine will run according to the code generated by the software slicer. This code will instruct the machine to move and do the printing according to the instructions

- Cleaning phase, the core at this stage is to do cleaning on the printing results. Printing results are not solely clean and have a shape in accordance with the model that has been made. Printing results have 2 large segments, models and support. Support is the result of printing that is used to support the shape of a hanging or floating model. Support must be removed so that the shape of the model is visible ${ }^{6}$
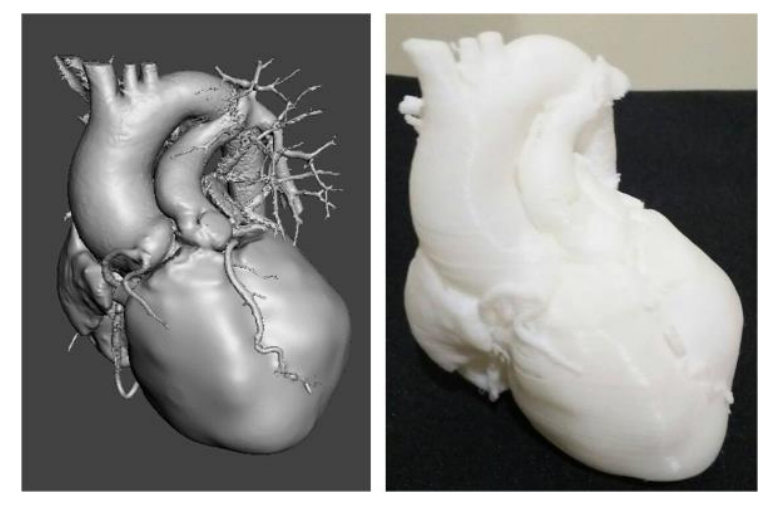

Figure 2. The comparison between pre-print data in STL format and the printed object. 
Here, some examples of study about use of $3 d$ printing in cardiology :

\begin{tabular}{|c|c|c|c|c|}
\hline Authors & Heart model & $\begin{array}{l}\text { Imaging } \\
\text { Procedure }\end{array}$ & Printing Method & Findings \\
\hline Costello et al. $^{11}$ & $\begin{array}{l}\text { Ventricle septal } \\
\text { defect }\end{array}$ & CMR & $\begin{array}{l}\text { PolyJet; rigid } \\
\text { materials }\end{array}$ & $\begin{array}{l}\text { 3D model to facilitate the } \\
\text { surgical procedure for planning } \\
\text { and improving orientation }\end{array}$ \\
\hline Greil et al. ${ }^{12}$ & $\begin{array}{l}\text { Normal and } \\
\text { congenital heart } \\
\text { model }\end{array}$ & CMR & $\begin{array}{l}\text { Laser sintering; } \\
\text { rigid material }\end{array}$ & $\begin{array}{l}\text { Accuracy of CMR-based } \\
\text { models }\end{array}$ \\
\hline Chaowu et al. ${ }^{13}$ & Atrial septal defect & $\begin{array}{l}\text { Computed } \\
\text { Tomography }\end{array}$ & $\begin{array}{l}\text { Not specified, } \\
\text { rigid model }\end{array}$ & $\begin{array}{l}\text { Pre-procedural planning of } \\
\text { transcatheter occlusion of ASD }\end{array}$ \\
\hline Little et al. ${ }^{14}$ & $\begin{array}{l}\text { mitral valve leaflets } \\
\text { and subvalvular } \\
\text { calcium deposition }\end{array}$ & $\begin{array}{l}\text { Computed } \\
\text { Tomography }\end{array}$ & $\begin{array}{l}\text { Not specified, } \\
\text { rigid model }\end{array}$ & $\begin{array}{l}\text { 3D Printed Modeling for } \\
\text { Patient-Specific Mitral Valve } \\
\text { Intervention }\end{array}$ \\
\hline Jacobs et al. ${ }^{15}$ & $\begin{array}{l}\text { LV with aneurysm; } \\
\text { RV tumor }\end{array}$ & $\begin{array}{l}\text { Computed } \\
\text { Tomography }\end{array}$ & $\begin{array}{l}\text { Binder jetting; } \\
\text { multicolor plaster- } \\
\text { based material }\end{array}$ & $\begin{array}{l}\text { 3D model facilitated surgical } \\
\text { procedure }\end{array}$ \\
\hline Deng et al. ${ }^{16}$ & $\begin{array}{l}\text { Normal heart } \\
\text { model }\end{array}$ & $\begin{array}{l}\text { Computed } \\
\text { Tomography }\end{array}$ & $\begin{array}{l}\text { Not specified, } \\
\text { rigid model }\end{array}$ & $\begin{array}{l}\text { The reconstructed humanheart } \\
\text { anatomical model, including } \\
\text { both the ventricles and atria }\end{array}$ \\
\hline Nicholls et al. ${ }^{1 /}$ & $\begin{array}{l}\text { Regions of scarring } \\
\text { in heart }\end{array}$ & CMR & $\begin{array}{l}\text { Not specified, } \\
\text { rigid model }\end{array}$ & $\begin{array}{l}\text { three-dimensional (3D) } \\
\text { imaging and printing is helping } \\
\text { to offer better understanding of } \\
\text { arrhythmias }\end{array}$ \\
\hline
\end{tabular}

\section{DISCUSSION}

The use of $3 D$ Printing in the manufacture of prototype machines / technical objects is based on fused deposition method. 3D FDM printers are the cheapest printer with the cheapest machine manufacturing costs. This is often used by engineering professionals in making machine prototypes or initial imitations of objects to be done using metal or larger machines.

There are some superiorities of this printing, such as :

- Faster production. 3D printing is faster than conventional manufacturing including injection molding and subtractive production. From prototypes to final products, the idea of testing 3D printing and design quickly. Faster design and prototype production means more time to repeat the prototype and find a product market match before competitors. 3D printing production only takes a few hours. Instead, testing ideas and designs with conventional manufacturing methods can take days, if not several weeks.

- Easy to access. 3D printing has been around for decades but it really did not take off until 2010. The explosion of interest in 3D printing has brought easier to use software and hardware to consumers because more competition is entering that space. It's never easier to learn technology and you can combine it 
in a matter of days into your production cycle.

- Better Quality. Traditional manufacturing methods can easily produce bad designs, and therefore poor quality prototypes. 3D printing allows assembly step by step from the object, which guarantees enhanced design and better quality objects.

- Cost effectiveness. With 3D printing, however, labor can be as little as one person issues a print order.

- Unlimited Forms and Geometry. The old method of manufacturing relies on mold and cutting technology to produce the desired shape. Designing complex geometric shapes can be difficult and expensive with this technology. 3D printing faces this challenge easily and there are not many technologies that cannot be done with the right supporting material.

- Less Waste Production. CNC cutting and injection molding produce a lot of wasted resources. Both involve removal of material from solid blocks. Unlike both, 3D printing only uses the material needed to make prototype parts - no more, no less. In addition, reusing materials from 3D printing is relatively straight forward. As a result, additive manufacturing only produces little waste, and saves a lot of money for the company.

The accuracy of 3D model is needed to achieve a better model by precisely demonstrating the complex structure and the abnormality of heart. ${ }^{7}$ Accuracy measurement process for heart models in this section are divided into two, namely the CT dimension and measurement validation on the patient's DICOM file. Both of these processes are sequential in order to produce high-accuracy cardiac anatomical models. Yoo et al. found that in congenital heart disease for example, the surgical technique is challenging. The size of heart is small and the access for operating the heart is limited. Thus, the rareness of certain congenital heart diseases further limits the chance to study and to improve the surgical skills ${ }^{8}$. Integration of multiple imaging modalities may be a good solution in acquiring high-quality medical images. A combination of multi-slice CT (MSCT) and 3D TEE produces a more ideal model compared with MSCT alone to get high quality of medical images. ${ }^{9}$ Errors can be happened during any step of the process, including image acquisition and segmentation. Although accuracy of the source images and appropriate choice of printing modality and materials are critical to achieve optimum accuracy, image segmentation and STL conversion remain the most error-prone steps. Giannopoulos et al revealed that there are two main factors that may reduce errors. First, an expert in the field who ideally is a doctor should perform the image postprocessing. This will ensure that the printed model is precisely fabricate the clinical interpretation of the images, because segmentation accuracy requires proper recognition of structures and their separation from imaging modality artifacts. Second, the segmentation software is so important. There is limited software designed for medical 3D printing, the specific medical application in segmentation data from CT Scan is suggested to produce high quality and accuracy of stl file. In this study we use mimic materialise software for segmenting dicom file from CT Scan. ${ }^{10}$

Limitations of the study

A limitation of our study is the lack of validation for evaluation the real dimension from model. The specific defect location also could not be fabricated precisely because of the difficulty to adjust the threshold in segmentation process to make STL file. The accuracy of a medical model depends on many factors especially the operator performing the virtual segmentation correctly. Besides, the reproducibility and accuracy is also depends on 3D printers specification regarding print resolution.

\section{CONCLUSION}

Making and implementing 3D printingof heart model has many advantages for medical education especially for the doctor, medical students or residents and also for the patient and its family to be more aware on the condition of the heart. This 
study may stimulate another trial of using this technique into several heart abnormalities.

\section{FUNDING SOURCE}

This research was funded by
"Direktorat Riset Dan Pengabdian
Masyarakat Direktorat Jenderal Penguatan
Riset Dan Pengembangan Kementerian
Riset, Teknologi, Dan Pendidikan Tinggi
Sesuai Dengan Perjanjian Pendanaan
Penelitian Dan Pengabdian Kepada
Masyarakat Tahun Anggaran 2018"

\section{ACKNOWLEDGMENTS}

We gratefully thank to the Department of Cardiology and Vascular Medicine of Gadjah Mada University, Gadjah MadaAcademic University Hospital, and Sardjito Hospital for their assistance and support in this research project.

\section{DISCLOSURE OF INTEREST}

The authors declare that they have no conflicts of interest.

\section{REFERENCES}

1. Rose A.S., Webster C.E., Harrysson O.L., Formeister E.J., Rawal R.B., Iseli C.E.2015. Pre-operative simulation of pediatric mastoid surgery with 3Dprinted temporal bone models. Int $\mathrm{J}$ Pediatr, Otorhinolaryngol, 79:740744.

2. Ventola C.L. 2014. Medical Applications for 3D printing: Current and Projected Uses. P\&T a peerreviewed. J Formul Manag, 39:704711.

3. VukicevicM., Mosadegh B., Min J.K., Little S.H. 2017. Cardiac 3D printing and its future directions. JACC Cardiovasc Imaging, 10:171-184.

4. Garcia J., Yang Z., Mongrain R., Leask R.L., Lachapelle K. 2018. 3D printing materials and their use in medical education: a review of current technology and trends for the future. BMJ Simul Technol Enhanc Learn, 4:27-40.
5. Salentijn G.I.J., Oomen P.E., Grajewski M., Verpoorte E. 2017. Fused deposition modeling 3D printing for (bio)analytical device fabrication: procedures, materials, and applications. Anal Chem, 89:70537061.

6. Iliescu M., Tabeshfar K., Ighigeanu A., Dobrescu G. 2009. Importance of rapid prototyping to product design. UPB Sci Bull Ser D Mech Eng, 71:117-124.

7. Sun Z., Squelch, A. 2015. 3D printed models of complex anatomy in cardiovascular disease. Hear Res, 2:103-108.

8. Yoo S.J., Thabit O., Kim E.K., Ide H., Yim D., Dragulescu A. et al.2015. 3D printing in medicine of congenital heart diseases. 3D Print Med, 2:3.

9. Luo H., Meyer-Szary J., Wang Z., Sabiniewicz R., Liu Y. 2017. Threedimensional printing in cardiology: Current applications and future challenges. Cardiol J, 24:436-444.

10. Mitsouras D., Liacouras P., Imanzadeh A., Giannopoulos A.A., Cai T., Kumamaru K.K. et al.2015. Medical 3D printing for the radiologist. Radiographics, 35:1965-1988.

11. Costello J.P., Olivieri L.J., Su L., Krieger A., Alfares F., Thabit O. et al.2015. Incorporating threedimensional printing into a simulationbased congenital heart disease and critical care training curriculum for resident physicians. Congenit Heart Dis, 10:185-190.

12. Greil G.F., Wolf I., Kuettner A., Fenchel M., Miller S., Martirosian P. et al.2007. Stereolithographic reproduction of complex cardiac morphology based on high spatial resolution imaging. Clin Res Cardiol, 96:176-185.

13. Chaowu Y., Hua L., Xin S. 2016. Images in cardiovascular medicine three-dimensional printing as an aid in transcatheter closure of secundum atrial septal defect. Circulation, 133:608-611.

14. Little S.H., Vukicevic M., Avenatti E., Ramchandani M., Barker C.M. 2016. 
3D printed modeling for patientspecific mitral valve intervention repair with a clip and a plug. JACC Cardiovasc Interv, 9:973-975.

15. Jacobs S., Grunert R., Mohr F.W., Falk V. 2008. 3D-Imaging of cardiac structures using 3D heart models for planning in heart surgery: a preliminary study. Interact Cardiovasc Thorac Surg,7:6-9.

16. DengD., Jiao P., Ye X., Xia L. 2012.
An image-based model of the whole human heart with detailed anatomical structure and fiber orientation. Comput Math Methods Med,2012:891070.

17. Nicholls M. 2017. Three-dimensional imaging and printing in Cardiology: Mark Nicholls reports on how threedimensional (3D) imaging and printing is helping to offer cardiologists a better understanding of arrhythmias. Eur. Heart J, 38:230-231. 